\title{
The Austrian national park strategy - aims and visions of Nationalparks Austria
}

\author{
Monika Paar
}

\section{Abstract}

Over the last ten years, the Austrian national parks experienced a period of intensive development. Major infrastructure and management projects were successfully completed during this time. The six national parks are now models of conservation in Austria.

Eventually, the wealth of joint projects and cooperations exceeded existing capacities for efficient organization, coordination and implementation. The lack of a jointly agreed nationwide orientation of national park policy also made itself felt. It would only be a matter of time before individual national parks would veer off in different directions unless something was done about it. In several workshops, the Federal Ministry of Agriculture, Forestry, Environment and Water Management, together with the national parks, developed a strategy for the future of the Austrian national parks. Subsequently, this strategy was discussed with the federal states and NGOs (Austrian League for Nature Conservation, Austrian Association of Alpine Sports, Austrian Friends of Nature, Environment Umbrella Organization and WWF Austria) and expanded further. It focused on efficient organization and coordination of joint multi-park actions for the six national parks under the overall brand Nationalparks Austria.

\section{The strategy}

In June 2010, the Minister for the Environment presented the two-part strategy to the public.

The first part spells out the concrete objectives of the national parks for the next five years in the shape of specific measures and success indicators. Here too, cooperation within the overall brand Nationalparks Austria is the foundation of progress. The strategy then describes the nine major themes and defines concrete objectives and their indicators for success. Some of the objectives and indicators listed are already being implemented, e.g. evaluating the management every 5-10 years or training highly qualified national park staff. Other aims, such as designating wilderness zones, creating ecological corridors between contiguous protected areas, producing joint presentations under the overall brand Nationalparks Austria and establishing a joint marketing and communication strategy are to be implemented in the coming years.

The new national park strategy also envisages structural changes in the cooperation between individual national parks and stakeholders. The coordination group now has a clearly defined task. It is the body that facilitates coordination between all national park directors and the ministry, advises and decides about joint projects and positions. A newly established national park advisory board, which includes representatives of NGOs and federal states, will make recommendations for the coordination group, thus ensuring the active participation of conservation NGOs.

Part B lists the objectives for Austria's natural heritage from the viewpoint of the national parks. One strategic aim is for the federal government to produce a 'natural asset report'. This natural asset report is to describe how the natural heritage has developed, to list threats and to report on positive effects already achieved, i.e. to produce a balance sheet of the Austrian natural heritage just like those for the monetary state budget.

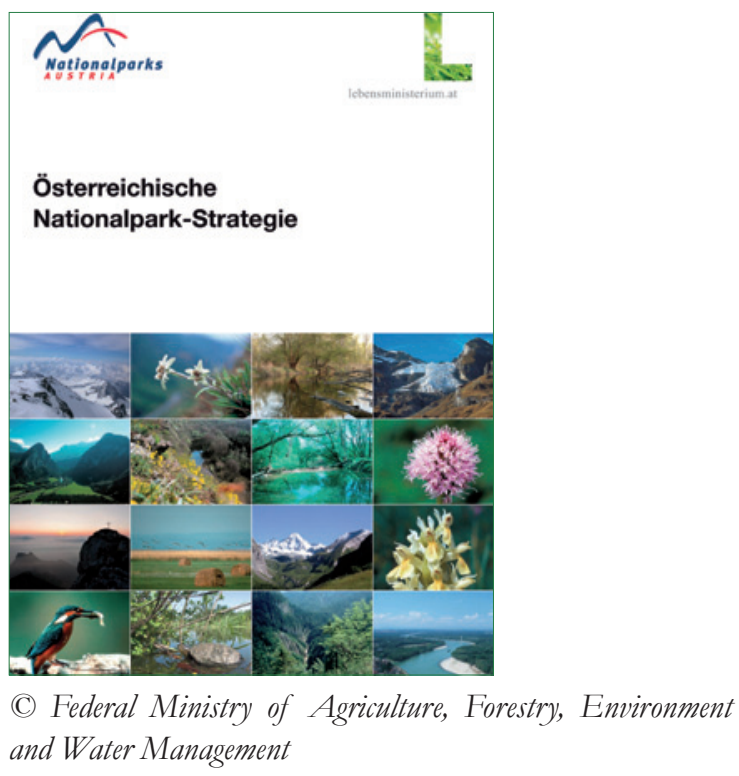

Another key strategic aim, which is also expressed in the new national park strategy, is deeply embedding the national parks in their regions. Close cooperation between national parks, the local economy, population and local authorities, which already exists in many places, is to be encouraged further.

In tourism, the choices for visitors are to be improved. National parks play a major role in regional tourism. Attractive options offered by the national parks shall be marketed to great effect by regional tourist boards and the Austrian Tourist Board. Business in national park regions shall strive to attain the standards of the tourism ecolabel. In future, national parks shall also play a role in regional food strategies, e.g. when national park regions jointly market their food products and cooperate with the established brand 'Genuss Region Österreich' promoting regional delicacies. The strategy also includes concepts of sustainable mobility: every national park shall be accessible by public transport.

www.nationalparksaustria.at 